\title{
NITRIC OXIDE PATHWAY AS A POTENTIAL THERAPEUTIC TARGET IN COVID-19
}

\author{
KHALID M. ALKHARFY, MUNEEB U REHMAN, AJAZ AHMAD * \\ Department of Clinical Pharmacy, College of Pharmacy, King Saud University, Riyadh, 11451, Saudi Arabia \\ *corresponding author: aajz@ksu.edu.sa \\ Manuscript received: July 2020
}

\begin{abstract}
The Covid-19 viral infection is linked to a severe pulmonary reaction, leading to an acute lung injury in a large percentage of affected patients. Various inflammatory pathways regulated by SARS-CoV-2 are under-investigated. Some potential therapeutic options aimed to alleviate the inflammatory response of SARS-CoV-2 infection are involving different strategies for blocking the activation of its binding receptors on host cells and immunomodulation. Given that excessive lung inflammation is likely to cause death in Covid-19 patients, using nitric oxide (NO) pathway to mitigate this risk appears to be a reasonable approach to avoid serious lung injury. Such therapy could be paired with systemic immunomodulatory therapy to combat the multiple organ damage of Covid-19. Therefore, regulating the NO pathway has a potential therapeutic strategy to minimize the mortality of SARS-CoV-2 infection.
\end{abstract}

\section{Rezumat}

Infecția virală Covid-19 determina o reacție pulmonară severă, provocând leziuni acute la un procent mare de pacienți. Căile inflamatorii activate de SARS-CoV-2 sunt incomplet cunoscute. Unele opțiuni terapeutice care vizează ameliorarea răspunsului inflamator în infecția cu SARS-CoV-2 implică strategii diferite la nivelul legării acestuia de celulele gazdă precum și un efect imunomodulator. Având în vedere că inflamația pulmonară excesivă poate provoca moartea pacienților cu Covid-19, utilizarea căii oxidului nitric (NO) pentru a atenua acest risc pare a fi o abordare rezonabilă pentru a evita leziunile pulmonare grave. $\mathrm{O}$ astfel de terapie ar putea fi asociată cu terapia imunomodulatoare sistemică pentru a combate leziunile multiple ale organelor afectate de Covid-19. Prin urmare, reglarea căii NO este o strategie terapeutică potențială pentru a reduce mortalitatea infecției cu SARS-CoV-2.

Keywords: nitric oxide, SARS-CoV-2, Covid-19, thymoquinone

\section{Introduction}

A novel coronavirus reported in late 2019 as a cluster of Pneumonia cases in Wuhan city in China. It spreads dramatically around the world and accompanied by a staggering number of cases in many countries. The World Health Organization (WHO) named the disease "Covid-19" which caused by coronavirus2 (SARSCoV-2). The understanding of Covid-19 is evolving, and WHO and the United States Centers for Disease Control and Prevention (CDC) have issued interim guidance for the disease [1, 2]. Certain investigational drugs such as hydroxychloroquine, azithromycin, tocilizumab, lopinavir-ritonavir and favipiravir have been used as treatment options. It is imperative to acknowledge however that there are no evidencebased data supporting the use of such therapies and their efficacy in Covid-19 is largely undefined. Other interventions of interest but with limited clinical data include interferon beta and convalescent plasma. More recently, the US Food and Drug Administration (FDA) has approved the experimental anti-viral drug remdesivir for emergency use in treatment of Covid-19 (www.fda.gov). Therefore, there is a clear priority to develop new strategies to combat this pandemic by better understanding the pathogenesis of the infection.

\section{Nitric oxide and virus infections}

Nitric oxide (NO) is an essential molecule for many physiological and disease-based processes. Indeed, NO has several biological effects such as muscle relaxation, in neurotransmission and also plays a vital role in body homeostasis [3-7]. NO is synthesized by the enzyme nitric oxide synthase (NOS), which comprises three known isoforms: endothelial (e), inducible (i), and neuronal (n) [3]. Both eNOS and nNOS) are constitutively expressed and regulated by transcription and post-transcription processes [8]. On the contrary, iNOS is released de novo in response to inflammation. Interestingly, the enzyme iNOS is expressed in leukocytes including neutrophils and macrophages [9-11]. In the defence against virus, iNOS is connected to phagocytosis following the activation by IFN- $\gamma$ 12-14]. For example, in influenza-induced pneumonia, NO release is greatly reduced in IFN- $\gamma$ deficient mice [3]. Moreover, the iNOS-inducing 
capacity in broncho-alveolar fluid of pneumonia caused by influenza virus is mostly due to the effect of IFN- $\gamma$ as indicated by an immuno-adsorption investigation using an anti-IFN- $\gamma$ antibody [15]. These results emphasize the role of IFN- $\gamma$ in iNOS upregulation and overproduction of NO in viral infections [15-19]. Since macrophages are the leading producers of NO during viral infections, this can significantly contribute to organ injury (Figure 1).

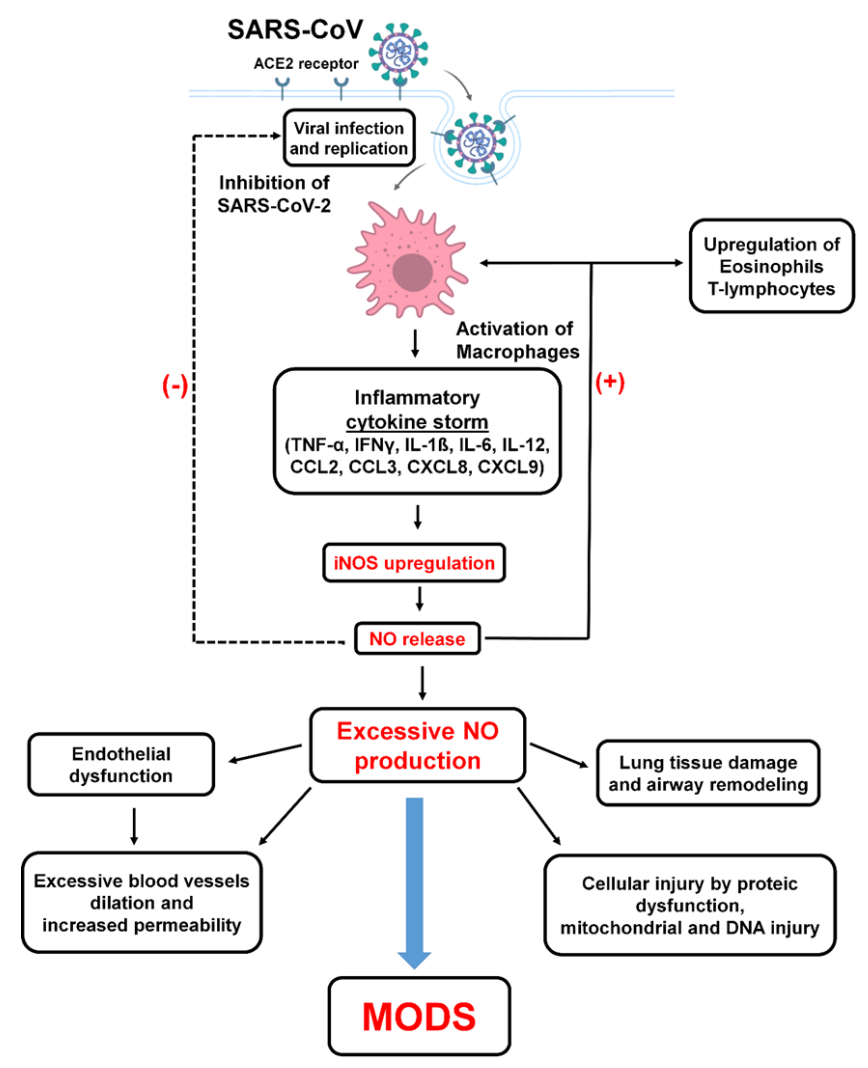

Figure 1.

The dual effects of nitric oxide (NO) in pathological conditions

NO can have both beneficial and detrimental effects. The production of NO during infections inhibits viral replication and mediates smooth muscle relaxation leading to bronchodilation and vasodilation. Large quantities of NO produced by iNOS in severe infections induce excessive immune cell responses, particularly by macrophages, eosinophils and T-lymphocytes. NO along with increased oxidative stress mechanisms can prime an uncontrolled cellular dysfunction, DNA injury, lung tissue damage, and endothelial dysfunction. Persistent effect of NO induces airway remodelling and mucus production by controlling the arginase pathway. (+) activation; (-) inhibition.

The cytokine storm, a lethal unregulated systemic inflammatory reaction resulted from the secretion of large quantities of pro-inflammatory cytokines, is one of the main causes of acute respiratory distress syndrome (ARDS) in many critically ill patients. These include the release of various cytokines (e.g., IFN- $\alpha$, IFN- $\gamma$, IL-1 $\beta$, IL-6, IL-12, TNF- $\alpha$, TGF- $\beta$ ) and chemokines (e.g., CCL2, CCL3, CCL5, CXCL9 and CXCL10) by immune cells in SARS-CoV infection $[20,21]$. The cytokine storm consequently prompts the release of significant amounts of NO. NO is generally advantageous both in normal conditions and during infection, allowing improved immune adaptation and immune cells migration through vascular epithelium [22]. However, NO has a mutagenic impact on the virus genome when presents in elevated concentrations as in the case with viral pneumonia [14]. In effect, high levels of NO found in the lungs of 1918 pandemic
$\mathrm{H} 1 \mathrm{~N} 1$ and $\mathrm{H} 5 \mathrm{~N} 1$ mouse models were attributed to neutrophils and macrophages [23]. This upregulated activity of the immune cells in the lung can lead to a massive release of inflammatory mediators and NO, which causes parenchymal tissues degradation, loss of usable alveolar surface and insufficient flow of gases, reduced respiration and eventually death. Respectively, the multiple organ dysfunction syndrome (MODS) may occur, which increases mortality in patients affected [24].

Currently, there are no approved methods to therapeutically modulate NO level under pathological processes. Potential pharmacological inhibition of NO is achieved via inhibition of NOS, inhibition of downstream signalling pathways and NO inhibition/ scavenging [8]. Two endogenous NOS inhibitors: asymmetric dimethylarginine (ADMA) is a potent, non-competitive NOS inhibitor while its NG-mono- 
FARMACIA, 2020, Vol. 68, 6

methyl-L-arginine acetate (L-NMMA, "Tilarginine") congener is a less potent, competitive inhibitor of NOS $[22,25]$. Dose-dependent L-NMMA increases the blood pressure by inducing human arterial vasoconstriction [25] and restore vasomotor tone balance in patients with septic shock, reducing concomitant norepinephrine treatment requirements [26].

The present evidence indicates that NO may interrupt the early stage of corona viral replication and deter its dissemination, facilitating clearance and host recovery [27]. Studies have, however, revealed that relative to the regular $\mathrm{H} 1 \mathrm{~N} 1$ isolates, pathogenic $\mathrm{H} 5 \mathrm{~N} 1$ and 1918 pandemic viruses can trigger more NO release in vivo and also by neutrophils derived from lung tissues subjected to 1918 virus ex vivo [15]. Interestingly, treatment with L-NMMA resulted in a substantial increase in the rate of survival of animals inoculated with H2N2 virus [15]. These findings were further reinforced by the observations that inhibition of NOS with L-NMMA has an advantageous impact on disease outcomes. By blocking NO production using selective NOS inhibitors or in NOS2-/- mice, a reduction in lung cytokine production was observed. In addition, there was a reduction in morbidity and death rates compared with controls [28]. Collectively, a significant function does exist for $\mathrm{NO}$ in the end result of H5N1 and 1918 pandemic infections in animal models.

A strategy based on using anti-inflammatory drugs has been advocated as a clinical alternative for patients with coronavirus infection [29]. Along with NO modulators, such treatment strategies may be successful in minimizing acute lung injury and MODS that are associated with Covid-19. However, the regulation of NO production should be gauged to maintain its positive antiviral effect while minimizing organ damage. Interestingly, natural compounds that demonstrated a prospective use, as inhibitors of NO, are under exploration. Notably, (-)-epigallocatechin-3-gallate (EGCG) inhibits mammary cancer cell migration, whereas proanthocyanidins inhibit non-small cell lung cancer cell migration by inhibiting NOS and guanylate cyclase (GC) [30]. Another compound which revealed imperative biological and pharmacological activities is thymoquinone [31]. This compound has shown remarkable anti-inflammatory and immunomodulatory properties, making it a potential candidate for further development for SARS-CoV-2 infection [32-34]. Further, thymoquinone exhibits a strong antioxidant action through a redox cycling mechanism and it modulates NO production. These properties are likely responsible for the protective effect of this compound against organ failure and mortality in severe sepsis $[32,33,35]$. Thymoquinone may also inhibit and interfere with SARS-CoV-2 binding to ACE2 receptors, which can prevent virus entry and replication inside the host cell $[36,37]$. Hence, targeting excessive NO production in SARS-CoV-2 infection constitutes an important area for future research in the quest for finding a cure for Covid-19.

\section{Conclusions}

In pathological conditions, regulating NO production by utilizing NO modulators/inhibitors to decrease the output of cytokines, reduced morbidity and delay in death should be encouraged. At present, there is no information concerning the levels of $\mathrm{NO}$ in COVID-19 patients. Thus, the consequence of NO modulation in SARS-CoV-2 infections using promising compounds like thymoquinone in animal models and patients constitute important areas for future studies.

\section{Acknowledgement}

The authors extend their appreciation to the Deanship of Scientific Research at King Saud University for funding this work through research group no. RG1441-337.

\section{Conflict of interest}

The authors declare no conflict of interest.

\section{References}

1. CDCP. Centers for Disease Control and Prevention. 2019 Novel coronavirus, Wuhan, China. Information for Healthcare Professionals, www.cdc.gov/coronavirus/ 2019-nCoV.

2. WHO. World Health Organization. Director-General's remarks at the media briefing on 2019-nCoV. www. who.int/dg/speeches/detail.

3. Akaike $\mathrm{T}$, Maeda $\mathrm{H}$, Nitric oxide and virus infection. Immunology, 2000; 101(3): 300-308.

4. Charville GW, Hetrick EM, Geer CB, Schoenfisch $\mathrm{MH}$, Reduced bacterial adhesion to fibrinogen-coated substrates via nitric oxide release. Biomaterials, 2008; 29(30): 4039-4044.

5. Constantin M, Şerban DN, Pricop C, Huzum B, Şerban IL, Extracellular $\mathrm{Mg}^{2+}$ level affects the major mechanism of endothelium-dependent relaxation in resistance arteries. Farmacia, 2019; 67(5): 888-891.

6. Umezawa K, Akaike T, Fujii S, Suga M, Setoguchi $\mathrm{K}$, Ozawa A, Maeda $\mathrm{H}$, Induction of nitric oxide synthesis and xanthine oxidase and their roles in the antimicrobial mechanism against Salmonella typhimurium infection in mice, Infect Immun., 1997; 65(7): 2932-2940.

7. Torre D, Pugliese A, Speranza F, Role of nitric oxide in HIV-1 infection: friend or foe?. Lancet Infect Dis., 2002; 2(5): 273-280.

8. Wong VW, Lerner E, Nitric oxide inhibition strategies. Future Sci OA, 2015; 1(1): FSO35: 1-5.

9. Perrone LA, Szretter KJ, Katz JM, Mizgerd JP, Tumpey TM, Mice Lacking Both TNF and IL-1 Receptors Exhibit Reduced Lung Inflammation and Delay in Onset of Death following Infection with a Highly Virulent H5N1 Virus. J Infect Diseas., 2010; 202(8): 1161-1170. 
10. MacMicking J, Xie QW, Nathan C, Nitric oxide and macrophage function. Ann Rev Immunol., 1997; 15(1): 323-350.

11. Szretter KJ, Gangappa S, Lu X, Smith C, Shieh WJ, Zaki SR, Sambhara S, Tumpey TM, Katz JM, Role of Host Cytokine Responses in the Pathogenesis of Avian H5N1 Influenza Viruses in Mice. J Virol., 2006; 81(6): 2736-2744.

12. Bi Z, Reiss CS, Inhibition of vesicular stomatitis virus infection by nitric oxide. J Virol., 1995; 69(4): 22082213.

13. Croen KD, Evidence for antiviral effect of nitric oxide. Inhibition of herpes simplex virus type 1 replication. J Clinic Investig., 1993; 91(6): 2446-2452.

14. Zaki MH, Akuta T, Akaike T, Nitric Oxide-Induced Nitrative Stress Involved in Microbial Pathogenesis. J Pharmacolog Sci., 2005; 98(2): 117-129.

15. Akaike T, Noguchi Y, Ijiri S, Setoguchi K, Suga M, Zheng YM, Dietzschold B, Maeda H, Pathogenesis of influenza virus-induced pneumonia: involvement of both nitric oxide and oxygen radicals. Proceed Nat Acad Sci., 1996; 93(6): 2448-2453.

16. Akaike T, Suga $M$, Maeda $H$, Free radicals in viral pathogenesis: molecular mechanisms involving superoxide and NO. Exp Biol Med., 1998; 217(1): 64-73.

17. Akaike $\mathrm{T}$, Maeda $\mathrm{H}$, Nitric oxide in influenza. In: Fang FC ed. Nitric Oxide in Infection. New York: Kluwer Academic/Plenum Publishers, 1999; 397-415.

18. Mehta DR, Ashkar AA, Mossman KL, The Nitric Oxide Pathway Provides Innate Antiviral Protection in Conjunction with the Type I Interferon Pathway in Fibroblasts. PLoS ONE, 2012; 7(2): e31688: 1-12.

19. Tuteja N, Chandra M, Tuteja R, Misra MK, Nitric Oxide as a Unique Bioactive Signaling Messenger in Physiology and Pathophysiology. J Biomed Biotech., 2004; 2004(4): 227-237.

20. Huang C, Wang Y, Li X, Ren L, Zhao J, Hu Y, Zhang L, Fan G, Xu J, Gu X, Cheng Z, Yu T, Xia J, Wei Y, Wu W, Xie X, Yin W, Li H, Liu M, Xiao Y, Gao H, Guo L, Xie J, Wang G, Jiang R, Gao Z, Jin Q, Wang J, Cao B, Clinical features of patients infected with 2019 novel coronavirus in Wuhan, China. Lancet, 2020; 395(10223): 497-506.

21. Li X, Geng M, Peng Y, Meng L, Lu S, Molecular immune pathogenesis and diagnosis of COVID-19. J Pharmaceut Anal., 2020; 10(2): 102-108.

22. Vallance BA, Deng W, De Grado M, Chan C, Jacobson K, Finlay BB, Modulation of Inducible Nitric Oxide Synthase Expression by the Attaching and Effacing Bacterial Pathogen Citrobacter rodentium in Infected Mice. Infect Immun., 2002; 70(11): 64246435.

23. Perrone LA, Plowden JK, García-Sastre A, Katz JM, Tumpey TM, H5N1 and 1918 Pandemic Influenza Virus Infection Results in Early and Excessive Infiltration of Macrophages and Neutrophils in the Lungs of Mice. PLoS Pathogens, 2008; 4(8): e1000115: $1-11$.

24. Angus DC, van der Poll T, Severe sepsis and septic shock. N Engl J Med., 2013; 369(9): 840-851.

25. Vallance P, Collier J, Moncada S, Effects of endotheliumderived nitric oxide on peripheral arteriolar tone in man, Lancet, 1989; 2(8670): 997-1000.
26. Grover R, Zaccardelli D, Colice G, Guntupalli K, Watson D, Vincent JL, An open-label dose escalation study of the nitric oxide synthase inhibitor, $\mathrm{N}(\mathrm{G})$ methyl-L-arginine hydrochloride (546C88), in patients with septic shock. Glaxo Wellcome International Septic Shock Study Group. Crit Care Med., 1999; 27(5): 913-922.

27. Akerstrom S, Mousavi-Jazi M, Klingstrom J, Leijon M, Lundkvist A, Mirazimi A, Nitric oxide inhibits the replication cycle of severe acute respiratory syndrome coronavirus. J Virol., 2005; 79(3): 1966-1969.

28. Perrone LA, Belser JA, Wadford DA, Katz JM, Tumpey TM, Inducible Nitric Oxide Contributes to Viral Pathogenesis Following Highly Pathogenic Influenza Virus Infection in Mice. J Infect Diseas., 2013; 207(10): 1576-1584.

29. Zhang W, Zhao Y, Zhang F, Wang Q, Li T, Liu Z, Wang J, Qin Y, Zhang X, Yan X, Zenga X, Zhang S, The use of anti-inflammatory drugs in the treatment of people with severe coronavirus disease 2019 (COVID-19): The Perspectives of clinical immunologists from China. Clin Immunol., 2020; 214: 108393: 1-5.

30. Punathil T, Katiyar SK, Inhibition of non-small cell lung cancer cell migration by grape seed proanthocyanidins is mediated through the inhibition of nitric oxide, guanylate cyclase, and ERK1/2. Mol Carcinog., 2009; 48(3): 232-242.

31. Ahmad A, Mishra RK, Vyawahare A, Kumar A, Rehman MU, Qamar W, Khan AQ, Thymoquinone (2-Isoprpyl5-methyl-1, 4-benzoquinone) as a chemopreventive/ anticancer agent: Chemistry and biological effects. Saudi Pharm J., 2019; 27(8): 1113-1126.

32. Alkharfy KM, Al-Daghri NM, Al-Attas OS, Alokail MS, Protective effect of thymoquinone in sepsis. 2014, In: US Patent 8, 625, US8895625B2, 2014.

33. Alkharfy KM, Ahmad A, Raish M, Vanhoutte PM, Thymoquinone modulates nitric oxide production and improves organ dysfunction of sepsis. Life Sci., 2015; 143: 131-138.

34. Shaterzadeh-Yazdi H, Noorbakhsh MF, Hayati F, Samarghandian S, Farkhondeh T, Immunomodulatory and Anti-inflammatory Effects of Thymoquinone. Cardiovasc Hematol Disord Drug Targets, 2018; 18(1): 52-60.

35. Alkharfy KM, Ahmad A, Jan BL, Raish M, Thymoquinone reduces mortality and suppresses early acute inflammatory markers of sepsis in a mouse model. Biomed Pharmacother., 2018; 98: 801-805.

36. Bouchentouf S, Missoum N, Identification of Compounds from Nigella Sativa as New Potential Inhibitors of 2019 Novel Corona virus (Covid-19): Molecular Docking Study. ChemRxiv Preprint, 2020; 1-12, https://doi.org/10.26434/chemrxiv.12055716.v1.

37. Sekiou O, Bouziane I, Bouslama Z, Djemel A, InSilico Identification of Potent Inhibitors of COVID19 Main Protease (Mpro) and Angiotensin Converting Enzyme 2 (ACE2) from Natural Products: Quercetin, Hispidulin, and Cirsimaritin Exhibited Better Potential Inhibition than Hydroxy-Chloroquine Against COVID19 Main Protease Active Site and ACE2. ChemRxiv Preprint, 2020; 1-22, https://doi.org/10.26434/chemrxiv. 12181404.v1. 